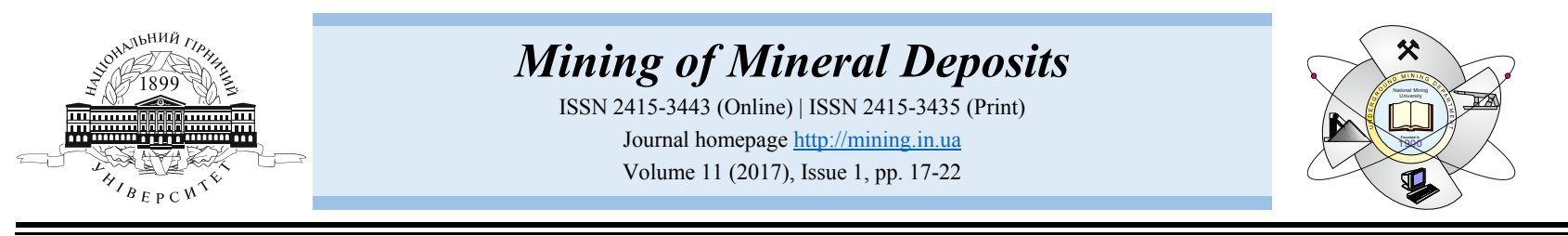

UDC 658:330.322:622.3(477)

https://doi.org/10.15407/mining11.01.017

\title{
COAL INDUSTRY IN THE CONTEXT OF UKRAINE ECONOMIC SECURITY
}

\author{
O. Mamaikin ${ }^{1 *}$, J. Kicki ${ }^{2}$, S. Salli ${ }^{1}$, V. Horbatova ${ }^{1}$ \\ ${ }^{1}$ Underground Mining Department, National Mining University, Dnipro, Ukraine \\ ${ }^{2}$ Division of Mineral Resource Acquisition, Mineral and Energy Economy Research Institute of the Polish Academy of Sciences, \\ Krakow, Poland \\ *Corresponding author: e-mail mamaykin@yahoo.com, tel. +380562479047,fax: +380562479047
}

\section{ВУГІЛЬНА ПРОМИСЛОВІСТЬ В КОНТЕКСТІ ЕКОНОМІЧНОЇ БЕЗПЕКИ УКРАЇНИ}

\author{
О. Мамайкін ${ }^{1 *}$, Є. Кіцкі ${ }^{2}$, С. Саллі ${ }^{1}$, В. Горбатова ${ }^{1}$ \\ ${ }^{1}$ Кафедра підземної розробки родовищ, Начіональний гірничий університет, Дніпро, Украӥна \\ ${ }^{2}$ Відділ освоєння мінеральних ресурсів, Науково-дослідний інститут мінеральної та енергетичної економіки Польської \\ академії наук, Краків, Польща \\ *Biдповідальний aвтор: e-mail mamaykin@yahoo.com, тел. +380562479047, факс: +380562479047
}

\begin{abstract}
Purpose. To rate the main factors and indicators of the national economic security, in particular the degree of the country's provision with primary natural resources which determine the global energy consumption trends.

Methods. Analysis of components comprising the fuel and energy complex of Ukraine in view of survivability and heuristic algorithm for finding economically feasible reserves. The problem of finding the optimal flow distribution is solved by graphs.

Findings. Emergencies are ranked in the descending order of optimal flows in the normal mode, the sorting sequence is defined, which results in the optimal solution via a minimum number of the algorithm computational steps.

Originality. A universal algorithm for the development of fuel and energy complex of Ukraine has been designed.

Practical implications. It was found that the vitality of integrated energy systems can be defined as the property to resist a large scale external disturbance, maintaining the ability to operate with acceptable performance and backup indicators. When considering large energy systems, the levels of the industry reserve can be reduced due to interchangeability of energy resources.
\end{abstract}

Keywords: fuel and energy complex, optimal flow distribution, performance indicators, emergency, industry reserve, energy consumption

\section{INTRODUCTION}

The paper analyzes peculiarities of fuel and energy resources planning in the context of emergency occurrences as well as ways to introduce changes in the structure of mine fund of coal industry in Ukraine in terms of unstable situation in the East of the country.

\subsection{General statement of the problem and its relevance to important scientific and practical tasks}

Each state strains after economic security and particularly security of energy supply. Thus, among a number of numerous indices of national economic security, Ukraine pays much attention to the degree of basic natural resources supply, specifically those of energy carriers. First of all, it is conditioned by scarcity of natural resources in general, and different levels of the resources availability in certain countries. That results in the potential threat of constant intensification of both economic and political struggle for their use.

\section{THE MAIN PART OF THE ARTICLE}

Nowadays, we observe a tendency for transformation of certain manufacturers' competition at the world market into the competition of national economies (when, for instance, ranges of national interests are declared). Raw materials resources have been, remain, and will always be the most important tool of both political and military pressure (Dold \& Friese, 2007).

For the sake of adequate economic security, any state should constantly implement legal, economic, and administrative measures aimed at protection of its own national interests relying on long-term strategy. As it is known, successful implementation of global strategic aims depends on economic policy making. It concerns primarily implementation of various purpose-oriented programs developed in light of economic projections; that is scenario of developments probability in all state and social spheres (Amosha, Kabanov, \& Starichenko, 2005). 
Following coventional current ideas of energy security, one should emphasize the duties imposed not only upon fuel and energy complex but also upon consumers, that is upon society at large. The latter presupposes limited demand for primary energy resources resulting from implementation of energy-saving policies. As experts believe, industries are governed by certain relations between gross domestic product and volume of product consumption. Consequently, simple extrapolation of demand for energy carriers basing upon private tendencies yields erroneous results (Zvyagil'skiy \& Zaloznova, 2013).

According to the reserves of own fuel and energy resources (FER), all countries are divided conditionally into rich countries, countries of middle wealth, and poor ones. However, it does not have a direct bearing on the level of their financial and economic health. Most countries in the world belong to the middle category in terms of fuel and energy reserves. In this context, their FER extraction is almost $20 \%$ of their domestic consumption. Germany, Poland, Sweden, Finland, France, Brazil and other countries are typical members of this category. Ukraine also belongs to this group as it is provided with its own raw FERs for almost $46 \%$, while such rich in raw FERs countries as the USA, Great Britain, Russia, Canada, Norway, oil-producing countries of Middle East, Turkmenistan have more than $70 \%$ of the resources they need (Dodds \& Bartram, 2016). Practically every country of the list above exports energy, while Japan, Italy, Switzerland, Hungary, Slovenia, and Croatia are among those countries that are poor in FERs as they have less than $30 \%$ of their need; that is why they have to import a good deal of energy (Pivnyak, Pilov, Salli, Amosha, Yashchenko, \& Il'yashov, 2004).

From the viewpoint of energy security, coal is a rather reliable fuel. There are considerable coal reserves in the world; means of its delivery are diverse and exercised from politically stable regions. World infrastructure is well-developed; coal is easily stored; thus new logistic setup is not a problem. The first and second oil crises have proved that coal prices were less susceptible to fluctuations than gas prices in the context of rising oil prices.

Determination of future role of coal as energy carrier for power supply of Ukraine should involve estimation of basic factors stipulating the above tendencies of global energy consumption. Practically each energy carrier has its own technological niche where its use is dominant or even exceptional.

\subsection{Analysis of the recent research which formed the problem solution}

Systemic studies in the field of energy sector are concerned with the analysis of giant hierarchical power structures forming general energy system of different territories (a country, a region, an economic area, a city, a town etc.). However, energy system is a multi-area complex - fuel energy complex (FEC) covering sector systems of coal-, oil-, gas-, and heat supply, power sector, and nuclear power industry. Comprehensive study of each part of FEC in correlation with the progress of both energy sector and economy of Ukraine as well as its regions makes it possible to implement systemic approach to solve the complicated and important problems of national economy (Sereda, 2014).
Such situation can be explained by the fact that planning of optimization methods of FEC and its branches at the top level can not reflect difficulties and diversities of local conditions which are of fundamental importance for regional energy sector that should provide interdependent and balanced development of prospecting, mining, processing, transporting, storage, and consumption of fuel and energy in the region. Thus, wide-range regional problems constitute the most important subclass of systemic research in the context of national economy. The task is of singular significance for Ukraine as a country with high level of industry and agriculture development, complexity of mining geological conditions and lack of fuel resources (except coal).

Decrease in the level of the country's self-sufficiency in terms of fuel resources brings about the necessity to develop intensive energy-saving policy. In the context of the country's FEC, planning means coordination of power resources progress with the progress of productive forces (Salli, Mamaykin, \& Smolanov, 2013). For this purpose, it is required to put a lot of effort to meeting the demands of industry, agriculture, transport facilities, housing and utilities infrastructure in different types of FER. FEC of the country is a multi-industry system; that is why its regional planning is based upon industries' development programs adaption to peculiarities of fuel and energy sector and conditions of FEC consumption.

\subsection{Basic research material and complete substantiation of the obtained scientific results}

Today Ukraine is affected by gas blockade iflicted by Russia. In fact, it is already the fourth gas war. Russian monopolist "Gazprom" stopped delivering fuel to Ukraine. Currently, Ukrainian gas transmission system only transits gas for consumers in EU countries. Terrorist operations in the east of the country ruin its energy infrastructure. Such situation needs not only measures to provide population with energy resources but also to provide energy sector with hi-tech equipment, the delivery of which to Ukraine is connected with integration of the country into the common EU space.

As it is known, Cabinet of Ministers imposed the state of emergency in the electric energy market. This measure has been brought forward by the problems of coal delivery to storages of thermal power stations which arose due to the situation in Donbas which impeded coal transportation. Taking into account the current gas problems, it is quite probable that coal deficiency can completely destabilize Ukrainian energy sector, and a considerable area of the country may be devoid of electric power. Donbas problems started before military operations when lack of budget funds resulted in reduced coal purchasing. However, serious troubles began in May with the break up of hostilities in the east of Ukraine. Today coal mining process in Donbas reached the lowest indices during its history (50\% decrease) (Sereda, 2014).

In the context of fuel and energy sector, the notion of reliability means determination of such structure of energy economy which would provide consumers with the required amount of necessary product (electricity and the energy carrier - heat, gas, oil, coal etc.) of adequate quality; besides situations potentially adverse to life and environment should be excluded. First of all, reliability is 
characterized by failure-free performance, stability, mode control, safety, and durability. Durability holds the most unique position among them as it is an exceptionally systemic property feature. It goes without saying that major disturbances (such as natural hazards or active external factors (i.e. military operations) are hardly predictable and cannot be clearly defined.

The situation requiring restoration of social stability and Donbas coal region potential, impaired by war, presents a multi-stage distribution problem. The essence of this problem is: it is vital to restore companies which are sources of energy as well as electricity consumers by the end of the planning period in spatially separated points of a given region. The options for mines' potential recovery and their maximum achievable capacity are known.

Let us introduce the following notation. $X_{l i}^{2 j}-$ volume of coal deliveries from $i$-th mine to the $j$-th power plant; $X_{2 j}{ }^{s}$ - electricity supply from the $j$-th power plant to $s$-th consumer; $X_{2 j}^{l i}$ - unused capacity of $l_{i}$-th mine; $f_{1}$ - the cost of producing one thousand tons of coal in $i$-th mine; $f_{2}$ - the costs of producing one million $\mathrm{kW}$-h of electricity by $j$-th power plant; $u_{i}$-the cost of transporting one ton of coal from $i$-th mine to $j$-th power plant; $\lambda_{i}$ - power losses and costs of its transmission from $j$-th power plant to $s$-th consumer; $M_{i}, M_{j}, M_{2 i}$ - the maximum possible capacities of mines, power plants and processing plants respectively; $D_{s}$-demand of $s$-th consumer; $\gamma_{i}$-need of $i$-th mine in electric power; $l_{1 i}, l_{2 i}-$ labour productivity at $i$-th mine and processing plant respectively; $L_{R}$ - the number of working-age population in the region.

The problem is described by the following system of relations.

To minimize:

$$
\begin{aligned}
& F=\sum_{i=1}^{n_{1}} \sum_{j=1}^{n_{2}}\left[f^{1 i}+u_{1 i}^{2 j}+\lambda_{1 i}^{2 j}\right] X_{1 i}^{2 j}+\sum_{j=1}^{n_{2}} \sum_{s=1}^{n_{3}} u_{2 j}^{s}+ \\
& +\sum_{j=1}^{n_{2}} \sum_{i=1}^{n_{1}} u_{2 j}^{1 i} X_{2 j}^{1 i}=\min .
\end{aligned}
$$

On condition that:

$$
\begin{aligned}
& \sum_{j=1}^{n_{2}} X_{1 i}^{2 j}+X_{1 i}=M_{1 i} \sum_{i=1}^{n_{1}} \lambda_{1 i}^{2 j} X_{1 i}^{2 j}+X_{2 j}=M_{2 j} ; \\
& \sum_{s=1}^{n_{3}} X_{2 j}^{s}+\sum_{i=1}^{n_{1}} X_{2 j}^{1 i}+X_{2 j}=M_{2 j} ; \\
& \sum_{j=1}^{n_{2}} \lambda_{2 j}^{s} X_{2 j}^{s}=D_{s} ; \\
& \sum_{j=1}^{n_{2}} \lambda_{2 j}^{1 i} X_{2 j}^{1 i}=\gamma_{i} \sum_{j=1}^{n_{2}} X_{1 i}^{2 j} \\
& \sum_{i=1}^{n_{1}} \frac{M_{1 i}}{l_{1 i}}+\sum_{i=1}^{n_{2}} \frac{M_{2 i}}{l_{2 i}} \leq L_{R} .
\end{aligned}
$$

The best indicators of a region development are living standards of its population. The living standard indicator has a complex structure. The core of it is the level of cash income. However, this level is also heterogeneous, as it includes incomes from production and non-production activities. Ultimately, it boils down to the necessity to ensure all members of society with a certain standard of living not worse than that in other regions. It is in this sense that we should talk about balanced development of coal-producing regions. These requirements are implemented in the production organization of each region, which is a specific territorial economic complex. It provides the most efficient development of productive forces in order to ultimately meet the demand of the country for finished coal products, manufactured in the region, and to satisfy the local needs most completely. Such are the highlights of planning economic development in the regions, distinguished by monoproduction - coal mining (Salli, Mamaykin, Ashcheulova, \& Salieiev, 2014).

Consequently, durability of integrated systems in the energy sector may be defined as an ability to withstand major disturbances (either unanticipated or consciously inflicted) preserving capability of functioning with acceptable indices of efficiency and backing up. While considering such energy systems as FEC, one should bear in mind that levels of the industry reserve may decrease owing to interchangeability of energy resources. Thus, durability in the context of FEC progress optimization is a result of intersystem backup.

The possible flow approach to optimizing the development of fuel and energy sector components taking into account its durability and heuristic algorithm comprises determination of the economically expedient reserve considering the following factors: mining, processing, and transportation of fuel and energy resources as well as their storage and consumption. To determine the optimum flow distribution is to solve generalized network transportation problem concerning a flow of minimum costs with limited possibilities of certain arcs (Kulik, Yufa, \& Dunaev, 1992). The sequence of emergency situations is considered in accordance with decrease in the flow value within arcs of the network in terms of standard operation mode. The algorithm is heuristic one as the obtained improved productivity of the network components is the baseline to meet the requirements of network nodes in case of any emergency situation.

Formalization of fuel and energy sector algorithm is shown in the form of oriented graph. As it is known, oriented network, or oriented linear graph $G=[N, A]$ consists of $N$ group of $x, y$ components together with $A$ set of certain normalized pairs of $(x, y)$ components taken from $N$. As the present paper is aimed at quantitative estimation of mine network capacity, it is assumed that $N$ is a finite set. Components of $N$ set are denominated in different ways: nodes, peaks, connection points or points; components of $A$ set are denominated as arcs, links, branches or edges. In our case, terms "peaks" and "arcs" will be used. Without limiting generality, we may suppose that the flow direction along each arc is known; and line-segment function of expenses consists of two parts that describe the current state of the component as well as its intensification (Ford \& Falkerson, 1966).

Thus, for each pair $(i, j)$, two arcs $\left(x_{i j_{1}}^{l}, d_{i j_{1}}^{l}\right)$ have been determined where $x_{i j}$ is the flow value in terms of an arc; $d_{i j}$ is capacity; 1 is emergency mode index $(l=1$ is the first emergency). 
In this context, emergency at the resource point (power plant, mine, oil-processing plant etc.) or emergency in traffic arteries (petroleum- and gas lines, railways etc.) are considered. Algorithm of successive intensification of the network in terms of emergency modes consideration is as follows (Kulik, Yufa, \& Dunaev, 1992).

Step one determines optimum flow distribution in the standard mode; that is if:

$l=0\left(x_{i j_{1}}^{-l=0}, d_{i j_{1}}^{l=0}\right) ;\left(0 ; d_{i j_{2}}^{l=0}\right)$.

Step two models the first emergency consequences and identifies optimum flow distribution. It is quite possible that emergency simulation will not result in $(i, j)$ intensification; that is arcs are transferred into capacity of the available one while the limitation in capacity of the intensified arc is reduced by:

$\left(x_{i j_{1}}^{l=1}, d_{i j_{1}}^{l=0}+x_{i j_{2}}^{l=1}\right) ;\left(0, d_{i j_{2}}^{l=1}-x_{i j_{2}}^{l=1}\right)$.

The algorithm has a universal nature regarding convex line-segment models of FEC progress as the convexity is used in the process of recomputing arcs capacity. Thus, the rank of emergency situations in the order of descending optimum flows values in the standard mode helps determine searching sequence resulting in optimum decision achieved by the minimum number of steps of computational algorithm. Given disruption of flow values along different arcs, the number of steps does not depend on their search order.

Currently the warfare has affected many mining towns, where mining industry is town-forming, and mines are generally unprofitable. $70 \%$ of coal is mined in private mines; which is explained by the fact that only best enterprises with vast reserves and newer stationary equipment went private. However, there are several stateowned unprofitable mines which are attractive for investors; that is why they should be maintained at the level of simple recovery. Another category comprises stateowned mines with sufficient reserves; though, their development is too expensive today. Such enterprises should be temporarily closed. There are also 30 dying enterprises (with 900 employees ) that should be closed as they produce only $50-70$ tons of coal a day. Thus, the state should allocate UAH $10-12 \mathrm{mln}$ from the budget for each of them monthly.

It should be taken into account that the reduction of domestic fuel production and the increase of its import deteriorate social situation, cut the number of jobs, worsen the overall social and economic state of the country. No country in the world except Ukraine grounds its energy strategy on the imported fuel ignoring its own energy carriers. Ukraine is the only country where volumes of natural gas consumption (mainly imported) are 1.7 times bigger than the volumes of coal consumption (of domestic production mostly). As a result, the share of expensive imported natural gas in Ukrainian FEC sector is twice as big as its share in the global FEC (45.5 and $22.8 \%$ respectively).

It is necessary to increase coal volumes and share (at the expense of the decrease in natural gas share) in terms of Ukrainian energy consumption. Such increase is possible (within the initial period at least) owing to the growth of the domestic production. If after reaching a certain level it will become clear that further growth of the output is not economically feasible; increase in coal consumption can be compensated partially by its import, given the world coal market is competitive and cannot be monopolized. Ukrainian government plans to enhance coal import and prohibits its export from Ukraine on order to direct it to the domestic needs. The country has already purchased one mln tons of coal from South Africa and started negotiation process with the USA on the delivery of coal or an alternative fuel required for thermal power stations.

Such transformation of Ukrainian FEC will improve both economic and social situation in the country. Besides, it will reduce foreign currency load on the national economy (Bensh, 2014).

In conditions of limited currency resources for energy carriers import and possibilities of their supply diversification, the above measures are the objective prerequisite for increasing the role of coal industry in maintaining energy safety of the state at an adequate level, and allowing for a certain flexibility in energy resources supply to Ukraine if the situation on the world energy market changes. However, lack of clear and qualitatively determined and legislatively formalized demands concerning reaching the required level of energy safety of the state, unprofitability of the majority of operating coal mines, and annually increasing need in state financial support stipulate uncertainty of the situation as for the strategic progress of the industry.

That is why the first step to overcome separatism consequences in Western regions of Ukraine is stabilization of the situation and further steady development of the coal branch in order to increase the level of energy safety of the state. In this context, economic priorities of the industry should embrace the demands of energy safety and principles of market economy.

\section{CONCLUSIONS}

1. Ukraine is on the threshold of the situation when lack of coal at thermal power stations (TPS) may result in irregularities of electric power supply. $42 \%$ of power generating facilities in the country use coal. Nuclear power stations generate other $58 \%$ of electric power. Unfortunately, TPSs using coal cannot replace nuclear power stations.

2. Planning of fuel and energy balance of Ukraine needs consideration of emergency situations which requires strengthening of certain resource stocks or transport communications.

3. Currently, it is essential to transform structural fund of the industry by increasing significance of coal in maintaining energy safety of the state, and ensuring certain flexibility in energy resources supply to Ukraine if it joins EU.

\section{ACKNOWLEDGEMENTS}

The authors express their gratitude to Laureate of National Prize of Ukraine, Doctor of Technical Sciences, Professor, Head of the Underground Mining Department, Volodymyr Bondarenko for his guidance while performing work on this topic. 


\section{REFERENCES}

Amosha, O.I., Kabanov, A.I., \& Starichenko, L.L. (2005). Perspektyvy rozvytku ta reformuvannia vitchyznianoi vuhilnoi promyslovosti na foni svitovykh tendentsii. Donetsk: IIeP NAN Ukrainy.

Bensh, R. (2014). Sleduyushchiy ukrainskiy krizis - ekonomicheskaya katastrofa. Mixednews, pp. 6-7. Retrieved from http://mixednews.ru/archives/63423

Dodds, F., \& Bartram, J. (2016). The Water, Food, Energy and Climate Nexus. London: Routledge. https://doi.org/10.4324/9781315640716

Dold, B., \& Friese, K. (2007). Biogeochemical Studies about the Environmental Impacts of Mining on Ground and Surface Water. Journal of Geochemical Exploration, 92(2-3), V-VI.

Ford, L., \& Falkerson, D. (1966). Potoki v setyakh. Moskva: Mir.

Kulik, M.N., Yufa, A.I., \& Dunaev, V.N. (1992). Optimizatsiya respublikanskogo toplivno-energeticheskogo kompleksa $i$ ego otaslevykh system. Kyiv: Naukova dumka.
Lee, S. Natural Resource Security in an Uncertain World. The Water, Food, Energy and Climate Nexus: Challenges and an Agenda for Action, 138.

Pivnyak, G.G., Pilov, P.I., Salli, V.I., Amosha, A.I., Yashchenko, Yu.P., \& Il'yashov, M.A. (2004). Vosproizvodstvo shakhtnogo fonda $i$ investitsionnye protsessy $v$ ugol'noy promyshlennosti Ukrainy. Kyiv: Naukova dumka.

Salli, S., Mamaykin, O., \& Smolanov, S. (2013). Inner Potential of Technological Networks of Coal Mines. Mining of Mineral Deposits, 243-246. https://doi.org/10.1201/b16354-46

Salli, S., Mamaykin, O., Ashcheulova, O., \& Salieiev, I. (2014). On the Building a System of Reduction of Loss Ratio Level of Coal Mines. Mining of Mineral Deposits, 8(1), 41-47. https://doi.org/10.15407/mining08.01.041

Sereda, A. (2014). Chto budet s uglepromom Ukrainy. Energetika Ukrainy (uaenergy), pp. 2-4. Retrieved from http://uaenergy.com.ua/post/19656/chto-budet-s-uglepromomukrainy/

Zvyagil'skiy, E.L., \& Zaloznova, Yu.S. (2013). O neobkhodimosti shirokoy modernizatsii ugol'noy promyshlennosti Ukrainy. Donetsk: IIeP NAN Ukrainy.

\section{ABSTRACT (IN UKRAINIAN)}

Мета. Оцінити головні чинники та індикатори національної економічної безпеки, зокрема ступеня забезпеченості країни основними природними ресурсами, які зумовлюють тенденції світового енергоспоживання.

Методика. Проведено аналіз елементів паливно-енергетичного комплексу України з урахуванням живучості та евристичний алгоритм знаходження економічно обгрунтованого резерву. Завдання знаходження оптимального потокорозподілення вирішене методом графів.

Результати. Проранжовані аварійні ситуації у порядку зменшення величини оптимальних потоків у нормальному режимі, визначено послідовність перебору, що призводить за мінімальне число кроків обчислювального алгоритму до оптимального рішення.

Наукова новизна. Розроблено універсальний алгоритм розвитку паливно-енергетичного комплексу України.

Практична значимість. Встановлено, що живучість інтегрованих систем енергетики можна визначити як властивість протистояти великомасштабним зовнішнім обуренням, зберігаючи здатність функціонувати із допустимими показниками ефективності та резервування. При розгляді суттєвих енергетичних систем рівні галузевого резерву можуть знижуватися за рахунок взаємозамінності енергетичних ресурсів.

Ключові слова: паливно-енергетичний комплекс, оптимальне потокорозподілення, показники ефективності, аварія, галузевий резерв, енергоспоживання

\section{ABSTRACT (IN RUSSIAN)}

Цель. Оценить главные факторы и индикаторы национальной экономической безопасности, в частности степени обеспеченности страны основными природными ресурсами, обуславливающими тенденции мирового энергопотребления.

Методика. Произведен анализ элементов топливно-энергетического комплекса Украины с учетом живучести и эвристический алгоритм нахождения экономически обоснованного резерва. Задача нахождения оптимального потокораспределения решена методом графов.

Результаты. Проранжированы аварийные ситуации в порядке убывания величины оптимальных потоков в нормальном режиме, определена последовательность перебора, что приводит за минимальное число шагов вычислительного алгоритма к оптимальному решению.

Научная новизна. Разработан универсальный алгоритм развития топливно-энергетического комплекса Украины.

Практическая значимость. Установлено, что живучесть интегрированных систем энергетики можно определить как свойство противостоять крупномасштабным внешним возмущением, сохраняя способность функционировать с допустимыми показателями эффективности и резервирования. При рассмотрении крупных энергетических систем уровни отраслевого резерва могут снижаться за счет взаимозаменяемости энергетических ресурсов.

Ключевые слова: топливно-энергетический комплекс, оптимальное потокораспределение, показатели эффективности, авария, отраслевой резерв, энергопотребление

\section{ARTICLE INFO}

Received: 25 October 2016

Accepted: 12 January 2017

Available online: 30 March 2017 


\section{ABOUT AUTHORS}

Oleksandr Mamaikin, Candidate of Technical Sciences, Associate Professor of the Underground Mining Department, National Mining University, 19 Yavornytskoho Ave., 4/58, 49005, Dnipro, Ukraine. E-mail: mamaykin@yahoo.com

Jerzy Kicki, Doctor of Philosophy, Head of the Division of Mineral Resource Acquisition, Mineral and Energy Economy Research Institute of the Polish Academy of Sciences, 7 Wybickiego St, 31-261, Krakow, Poland. E-mail: jkicki@min-pan.krakow.pl

Serhii Salli, Candidate of Technical Sciences, Associate Professor of the Underground Mining Department, National Mining University, 19 Yavornytskoho Ave., 4/62, 49005, Dnipro, Ukraine. E-mail: ad000957@yandex.ua

Viktoria Horbatova, Student of the Underground Mining Department, National Mining University, 19 Yavornytskoho Ave., 49005, Dnipro, Ukraine. E-mail: vika_v62@mail.ru 